$\xi=-1$

\title{
Timeline of Records Management in Indonesian Universities (Case Studies of Faculty of Engineering, University of Indonesia)
}

\author{
Dyah Puspitasari Srirahayu, S.Kom, M.Hum \\ Program study Technician Library, Vocational Faculty, Universitas Airlangga, Surabaya Indonesia \\ *Corresponding author E-mail: dyah.srirahayu.vokasi.unair.ac.id
}

\begin{abstract}
The aim of this research is to understand the development records management in universities, especially in Faculty of Engineering, University of Indonesia (FT UI). Records management is required to ensure the accountability and transparency of an organization. In order to manage it, a specific unit is needed. This research uses qualitative approach with case study method to provide a complete description of how is the development of records management in FT UI overtime. It can be found in the result that from year to year, the records management in FT UI does not have a clear structure even though the occupation is available and goes well. The employees do records management based on their knowledge that they have and inherited from generation to generation.
\end{abstract}

Keywords: organization structure, organization, management of record, record

\section{Introduction}

Globalization shapes every organization to grow according to the demands of the time and its growing competitors. Organization needs to continually make progress and maximize its structure and system. By doing so, the diversity of tasks and operational needs of company performance can easily be encountered. The human resources that exist within the organization are the key to the success of the organization's vision and mission.

Organization is a group of people that is systematically structured to achieve the organization's goal; each person has their own role that has been formally set in job description [1]. Organization structure is a set of plan from the Head that determine expectations regarding to what members and the organization itself should do to achieve the goals [2].

Each member collaborates to organize and implement the organizational functions in the form of substantive and facilitative activities. Substantive activity is main organizational activity, as stated in the organization's vision and mission; on the other hand, facilitative activity is an activity that supports the substantive activity. The organization function is a written commitment from the organization to resolve the main goal. In implementing the function, the organization would always involve new information. Each organization surely produces and need information in implement their business activity. It means that the organization can only be carried on as long as it manages information, whether it accept or create.

Information that is recorded in every working unit relates with it working activity, which is call as record, or in Indonesia known as archive. Record is a result of participation (by product) organizational business function activity and useful for evidence of organization activity. ISO 15489 part 1 [3] defined record as an information that is created, received, and managed as an evidence for organization to fulfill legal needs or in business transaction. Whereas according to Law Number 43 in 2009 archive is a record of activity or an event in a various form and media that appropri- ate with the development of information technology and communication, which created and received by the state institution, local government, educational institution, company, political organization, civic organization, and individual in implementation of social life, nation, and state [4].

An organization needs a management in order to reach its goal. Management is a board which direct its people within the working units in order to reach the organization's goal [5]. Robbins \& Decenzo explain that management is a process to accomplish certain job efficient and effectively by and through its people [6]. The success of a project depends on many things, and one of the most important things is the leader and person in charge. It is also applied to the records management. The person in charge and the leader of records management is called records management.

Manager is a part of a structure which consists of rules and policies regulating ones' position in an organization. Manager's role can not be separated from authorities and responsibilities as a position logic consequence whereas responsibility and authority can not be separated from accountability [7]. Individual accountability must be brought together with roles, and they can not be held accountable for actions they have done if they have no authority or responsibility for it. Accountability is a principle that a person, organization, and society is responsible for their actions and necessarily needed to explain those actions to others (ISO 15489: Part 1, 2001) [3].

This research intends to give an idea about how organization structure development works in a university in Indonesia, on records managementof the organization. With the result guidance and also examples on how records management goes well in an organization.

\section{Method}

This research is using qualitative approachfor it intends to give comprehension and idea about the progress and records management, in which organization condition can be seen from 
the development of its structure in supporting the organization's business function. The method that is used is case study because not only to answer "how" and "why", but also to know the organization structure development in supporting business organization function. The case study is used to emphasize occurrence and tendency ongoing nowadays within real life context and to achieve the whole and deep picture about an event [8].

This research takes place in FT UI because based on the previous research, in records management in UI, the record manager does not make any manuals or written guidance in its administration, substantive function nor facilitative function [9-10]. Therefore, the administration staffs have done it based on their own knowledge of it because the lack of policy in guidance form and also briefing from the record manager [11]. Faculty of engineering is a faculty that creates graduates who are ready to work based on job rules and guidance.

The research subjects or informants that is used in this research are the dean, faculty secretary, the General Manager, the dean's secretary (Ms. Kamti), expedition staff (Mr. Jendol), personnel department staff (Mr. Tono), academic staff. The informants selection is more emphasized on what data is going to be seek, who are the people considered to know and able to give the real information.

Data collection was conducted using 1). Interviews as the important information sources for case studies [12]. The interviews were conducted using open-ended questions, so that the informants could provide clearer answers. During the interviews, the researchers recorded and made notes on the important points. While the interview overed, the researchers made transcript reduced by simply keeping track of the topics by comparing the results of the notes and summarized them. 2). Documents, to support and as the evidences from other sources. The relevant documents in this study, for example, arethose related to organization structure, job description of each function, working procedure (job description) Records Manager and his staff, standard operating procedures (SOP) in carrying out the business functions of the organization related to the management of records and other related documents.

Stages in data analysis are as Miles and Huberman (in Idrus) stated: 1). Collecting all raw data generated from interviews, documents and live observations. Then the data is recorded as it is. 2 ). The data are then reduced by selecting the appropriate and non-appropriate managing the records. 3). The data are then compiled and linked to the concept or keywords, causal flow and provide explanation / interpretation of the researcher presented in the form of explanatory or descriptive explanation. 4). Drawing the initial conclusion to take further action such as deepening interviews or observations. 5). The verification process is condected by doing cross-check (combining and comparing with other sources, previous findings, and literatures. 7). The last thing to do is to make a final conclusion if the data has reached the saturation point [13].

\section{Findings}

As the evidence of organizational activities, records need to be well managed. Records management is a systematic control of the records covering the recording life cycle process (ARMA dictionary) [14], from creation or acceptance, through a process, distribution, management, storage and rediscovery to disposition. This management also functions as a control of the records other than as the evidence and conveyance of information [5].

\section{a. Before 2000}

The records management of FT UI, based on the organization structure of 1999 , is under the authority and responsibility of the head of general administrative affairs/archive of archival sections as set forth in the 1999 work descriptions referred to by some employees as "White Book" namely: 1) Preparing personnel files;
2) Saving and giving important document numbers; 3) Helping in searching documents when needed; 4) Making a report of documentation activities and 5) Maintaining and arranging the documents.

The document is the recorded information produced by the organization while the records are documents that become evidences of the business activities of the organization so that eventhough it is not mentioned by the term records, but the Archive Section is responsible for the management of records.

The Archives section consists of four employees: Mr. Dono, Ms. Erni, Mr. Sudar and Mr. Jendol. Mr. Dono is in charge of managing the FT UI records both in and out, by making copies of the existing records. While the original ones are on the employees responsible for the records. The employees manage the records, they are responsible for, based on the knowledge and the habits. Mss. Erni is as a duty to record the document entry FT UI and give number to FT UI important documents. Mr. Sudar is responsible for the distribution of documents within FT UI, while Mr. Jendol is responsible for outside expedition section of FT UI. Recordkeeping is part of the management which responsible for the efficiency and control over the creation, acceptance, management, use, and disposition of the records and the provision of complete, accurate and reliable business transaction evidence in the form of recorded information. Recordkeeping is an action of documenting activities by creating, collecting or receiving records and ensuring that the records are available, understandable and useful as long as they are needed. The recordkeeping system is a business information system designed as a proof of business activity, managing records and providing whene necessary ${ }^{18}$. Recordkeeping includes staff, rules, procedures, tools, technology, user education, and maintenances [15].

\section{b. $\quad 2000-2005$}

Organization is something dynamic ${ }^{10}$, in which each element is integral to each other and if one element changes, then it will change the others. Those elements are processes, structures, tools and people. The process means that the organization designs or builds or provides services by conducting activities that convert inputs into outputs. Structure means that the organization has an almost permanent framework consisting of several designs of material source processes and individuals in several stages and those stages are hierarchical. Pernagkan is a tool to helps individuals in carrying out tasks that will influence administrative control while the individual is the executor of the work.

This also happened in FT UI where in 2000, FT UI experienced organization structure change from PTN to BHMN based on Government Regulation Number 152 Year 2000 about the establishment of University of Indonesia as BHMN. In 2000 the management of the record was still under the responsibility of the Archives Section even though it was not in the organization structure anymore. Leaders of FT UI assume that the records management job is a routine job and all people can do it without being a member of organization structure explicitly and so far there is no problem in records management for FT UI [16]. Gover in Sri Rahayu reveals in his research that the managers and managers of records themselves think that their managerial role is only a supporting role in which the records management work is more structured and routine so it does not need to be the main focus because the job of managing the record is still running even without structure or guidelines [15, 17]. Basically aspects of organization structure may affect certain aspects of effectivity; for instance, the staffs feel more pleased if they get to experience bigger responsibility, the tasks allow them to be more involved and work on more variation, the terms and regulations are limited, and the organization and the working groups are not too big (Steers, 1984). Organization Structure of FT UI in year 2000 was not found by the researcher and according to Ms. Kamti, in that year the leader did not create chart of organization structure and job description of structural acting. In 2001 there was a fire in Dean building which destroyed all of FT UI Dean's records. 


\section{c. 2005-2015}

In 2005, there was a change of Dean in FT UI which resulted in the organization structure of FT UI which changed according to the parent of the University of Indonesia so that in 2005 the records management was under the responsibility of the Faculty Secretary at PAF (Faculty Administration Center) as contained in job description year 2007 based on Decree of Dean No. 028 / D / SK / FTUI / I / 2007 whose duties and responsibilities are: General Affairs and Archives in charge of 1) External and Inward Expedition Section and 2) Public Administration Section and Archives.

General Affairs and Archives are still managed by four employees with the duties of each employee as above. In $2007 \mathrm{Mr}$. Dono died, while Mrs. Erni and Mr. Sudar retired. Employees who died and retired at that time were not replaced by other employees. General Affairs and Archives staff is only one person left, $\mathrm{Mr}$. Jendol who is responsible in terms of expedition.Employee turnover was not done as Ms. Kamti stated that there was no change of staff because the leader did not feel the importance of the archive management job and all had been handled by each employee. It is also affirmed by the Faculty Secretary that there is no change of staff because in the new structure Kaur's position, the section is no longer so that if replaced by the employee can cause misunderstanding and hope for the employee who is given the task. It is also supported by the General Manager that there is no employee turnover for cost efficiency and maximizing the employees.

FT UI leaders still consider that the work of administrative affairs and archives is handled by one person with the assumption because there has been no problem with records management. During this time, FT UI leaders saw that the work of managing the record has been going well, as disclosed by the Dean and Faculty Secretary where at the time leaders need information or records will always be searchable and found by employees. The same thing is also expressed by some employees where they rarely get a reprimand related to the record required by the leadership. If all the work is done without any problems, the leader or manager will not make improvements and control over the work [18].

Being a dynamic organization, eventually in 2008, a change was made in its management and leadership. This changes later affected the Organization Structure. Based on the Dean's Letter of Statement No431A/D/SK/FTUI/V/2008 (see Fig.1), the records management, which was done according to the Organization Structure in 2008, is a part of the shipping unit under the authority and responsibility of the General Manager. The shipping unit was handled by Mr. Tono, but he was only assigned to deliver letters which were received and sent through his unit. He also took record, however, it was done only if he had the time. It can be seen that the shipping unit has no responsibility over FT UI records management. In 2008 the records management was solely the responsibility of each staff, and all this time the staffs assumed that all of the faculty's records were with Ms. Kamti. Meanwhile, according to Ms. Kamti herself, the record which she managed was only those related to the Dean and the records management is a responsibility of each staff in the Faculty of Engineering.

Records management in an institution can be established as a unit on their own or become a part of the other units ${ }^{8}$ as can be seen in FT UI, in which serves under the responsibility and authority of the General Manager. In the records management unit of a structured organization, the one which has to be highlighted is always the staffs who manage the record; they should be able to cooperate with each other for record tracking can involve more than one inits. Take the presence record as an example, it is not only being used by the academics but also by the human resources unit in case they need to make a letter of assignments, the facility unit to know which rooms are being used and need more stationaries, the financial unit to decide the salary which need to be paid to the lecturers, and sometimes are used by the lecturers themselves to take decisions in grading the students. Aside from that, records management also needs to be supervised by the the General Manager. Supervision (control) is a mechanism or guide to operate and control a system. Supervision has an important management function so the manager could ensure that the system or program is working according to what it is assigned to do and to control and supervise [19], comparing with the standard of archive management as stated in the UU Kearsipan (Archives Regulation) would be needed. It is emphasized that there are four main guidelines in managing archives; 1) national services archives management guidelines; 2) archive clarification guidelines; 3) archives retention schedule guidelines; 4) archives access and safety clarification guidelines.

In FT UI, the General Manager is responsible of job assigning and techincal procedures of records management, as well as briefing and controlling every task related to records management done by the staffs everyday. The manager is also responsible for coaching the staffs, involving them in workships, seminar, or training about records management where every staff is responsible towards their unit leader. Therefore, the record manager needs to cooperate with the managers of other units so the objective of records management as follow could be attained:

Deciding the needs of records management related to the business of each unit; such as what records are needed and should be kept for how long.

Develop rules and working procedure to support the creation and keeping of a complete and accurate reccord.

Develop systems and controls to ensure the complete and accurate record tracking.

Develop systems and services which provide efficiency and access towards all records.

- Ensures that the organization is ready to be audited by teams from outside the organizations such as KPK and BPK.

\section{d. $\quad 2015-2016$}

In 2016 the organization structure in the faculty has gone through changes as seen in the FT UI's official website (http://eng.ui.ac.id/pimpinan-fakultas/). However, the records management is still functioning under the General Manager. In the faculty, the manager's role in managing the record has not yet been significance for there is no obvious job description in the faculty during the process. According to Mitzberg a role in a job can only be done effectively by the manager when every effort and time is focused towards only one function, as how it should be according to the organization structure mapping and general job description [20]. In the Faculty of Engineering of University of Indonesia, the General Manager has no authority in creating a certain regulation, it can only be made by the dean or vice dean. The General Manager also has more than one unit to manage; facility and human resources. According to Kast and Rosenzweig a manager, in doing their job, are faced with demands, which later serve as an obstacle that results in them choosing the job they'd like to do and how they do it [21]; in the Faculty of Engineering, this can be seen from how the General Manager prefers more on working in the facility and human resources unit.

All this time, the function of the management record on the FT UI still looked as a symbolic role which in the organization structure, the macro one is hold by university secretary who has responbility in all record policies and the micro one. In other hand, based on command line, is on the hold of faculty secretary. This matter also happened to the General Manager who also has a symbolic role based on the job description. However, all the works in the management record should be done well without any problen as long as the heads do not feel any difficulty to get the records that they needed. The staffs on the FT UI should possess a value, that they got from their own experiences and their co-workers', so they can establish their works. Moreover, they should adopt and develop a habit to manage the record easier so they can control the work situation and made regular decision that already programmed. The record retrieval should be managed based on the job agreement. Based on Kennedy, the key component for record retrieval is its speed and accuracy when it is needed for 
operational program, reference, decision making, law matter, education, and research. In the record retrieval on the Faculty of Engineering in UI, every work units has an agreement to decide the needed index for the record retrieval which is not included in the guidelines but in the data input.

Based on the archive regulation number 43 in 2009, a university must has archival unit in university level and record center in faculty level for securing the quality of the archives that good, systematic, authentic, and trusted. If a university does not have them yet, there will be an administrative punishment for it. In Indonesia, not all universities already done what the constitution wants because the lack of supervision for the implementation of it. From this problem, the government should take a role to supervise the university to do what the constitution said.

\section{Conclusion}

The records managementof FTUI works well every year. This can be seen from the good retrieval information and the lack of problems from head in the matter of the records that they need to make a decision even though they do not have the fix structure for years. The explanation about the role and fiction is not explicitly stated by the organization structure in there. The staffs manage the archives based on the inherited habit from the previous generation to the next one (regeneration). Even the records management guidelines were already made for the university scale, it does not work well in the faculty scale which is caused by the lack of the head control over the implementation of that guidance.

\section{References}

[1] Hatch, Mary Jo. (1997). Organization Theory : Modern, Symbolic, And Postmodern Perspectives. Newyork : Oxford University Press

[2] Ivancevich, John M. Konopaske, Robert. Matteson, Michael T. (2007). Perilaku Dan Manajemen Organisasi. Jakarta: Penerbit Erlangga

[3] ISO 15489 (2001). International Standard. Information and Documentation - Records Management - Part 1: General

[4] Indonesia. (2009).Undang-undang RI No.43 Tahun 2009 Tentang Kearsipan. Arsip Nasional Republik Indonesia (ANRI). Jakarta: ANRI

[5] Lawanda, Ike Aswary. (2006). Mengelola Data Informasi Perkantoran. Bogor : Penerbit Akademia
[6] Robbins, Stephen P., \& DeCenzo, David A. 2004., Fundamentals of Management: Essential Concepts and Applications. English: Prentice Hall PTR

[7] Mustofa, Anwar.(2002). Model Sistem Pengelolaan Rekod di Program Studi dan Fakultas : Studi Kasus pada program Studi terakreditasi " $A$ " di Universitas Indonesia. Depok : FIB-UIISO 15489 (2001). International Standard. Information and Documentation - Records Management - Part 1: General

[8] Yin, Robert K.(2002). Studi Kasus :Desain \&Metode. Editor: M Djauzy Mudzakir. Jakarta: PT Raja Grafindo Persada

[9] Mustofa, Anwar.(2002). Model Sistem Pengelolaan Rekod di Program Studi dan Fakultas : Studi Kasus pada program Studi terakreditasi " $A$ " di Universitas Indonesia. Depok : FIB-UI

[10] Suprayogi, Mukmin. 2006. Kajian tentang pengelolaan rekod aktif kasus pada Fakultas Sastra Universitas Indonesia. Depok:FIB UI

[11] Siswadi, Irman. 2004. Kajian tentang penyusutan rekod pada Biro Administrasi Akademik dan Biro Administrasi Kemahasiswaan di Pusat Administrasi Universitas Indonesia. Depok:FIB UI

[12] Yin, Robert K.(2002). Studi Kasus :Desain \&Metode. Editor: M Djauzy Mudzakir. Jakarta: PT Raja Grafindo Persada

[13] Idrus, Muhammad. (2007). Metode Penelitian Sosial. Bogor: GhaliaIndonesia

[14] ARMA

International.GlossaryofRecordsandInformantionManagementTerm s.http://www.arma.org/standards/glossary/index.cfm? searchfor=records+manager submit=search

[15] Office NSW Records, DIRKS Manual, Introduction, 2003, http://www.records.nsw.gov.au

[16] Srirrahayu, Dyah Puspitasari. 2015.Implementing Role of record Manager in Faculty of Engineering University Indonesia. Bangkok : ALIEP

[17] Srirrahayu, Dyah Puspitasari. 2015.Implementing Role of record Manager in Faculty of Engineering University Indonesia. Bangkok : ALIEP

[18] Pfeffer, Jeffry. \& Gerald R. (1981). The External Control of Organizations a Resource Dependence. http/www.books.google.co.id/book? ISBN=080474789x (23-052011)

[19] Robbins, Stephen P., \& DeCenzo, David A. 2004., Fundamentals of Management: Essential Concepts and Applications. English: Prentice Hall PTR

[20] Mitzberg, H. (1975). Manajerial Work : analysis from observation. Management Science, 18, 2, oktober 1971, 97-110

[21] Kast, Freemont E. \& Rosenzweig, James E. (1996). Organization and Management. Alih Bahasa Hasyim Ali. Jakarta : Bumi Aksara

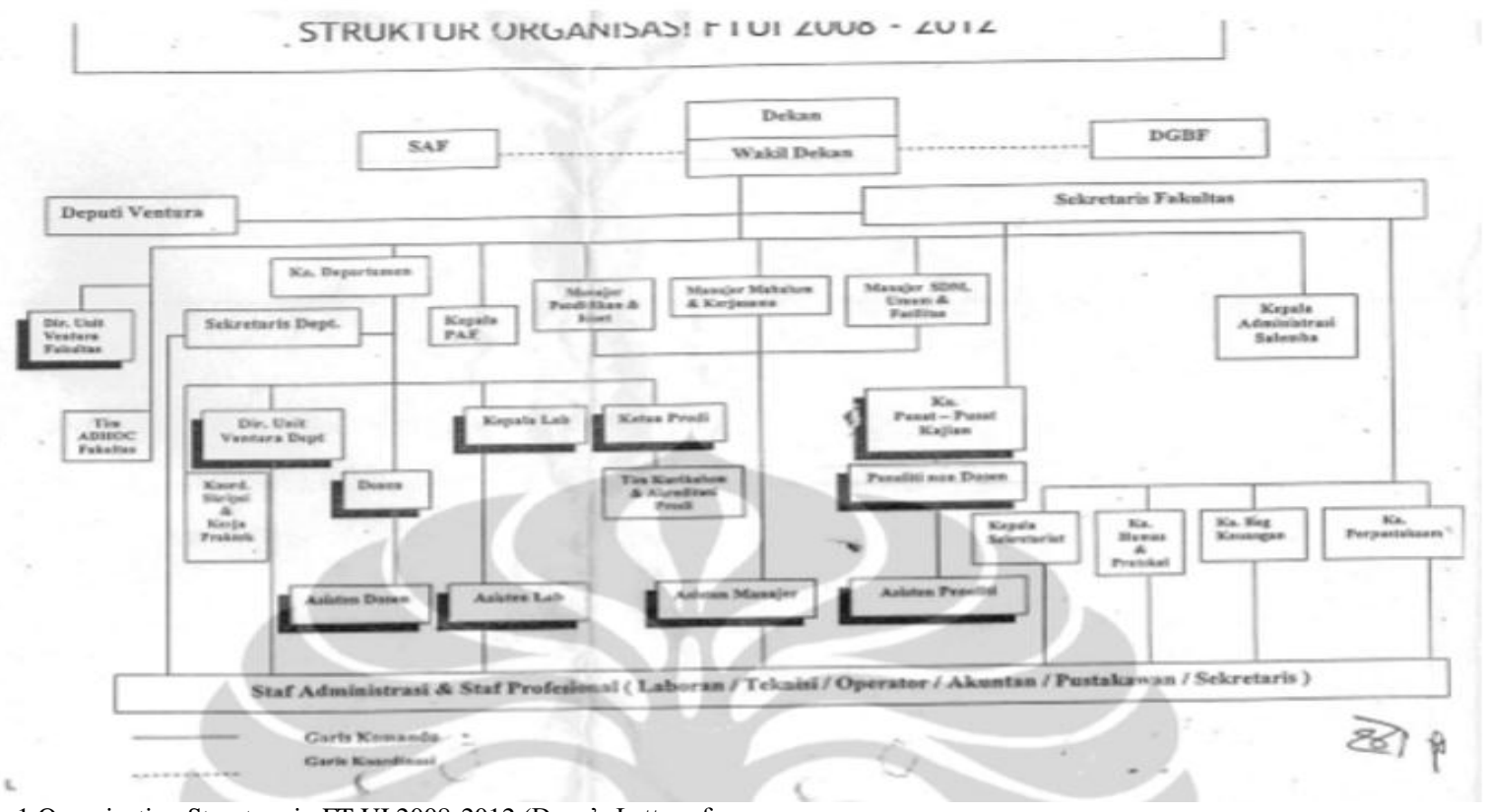

Fig. 1 Organization Structure in FT UI 2008-2012 (Dean's Letter of

Statement No431A/D/SK/FTUI/V/2008) 